\title{
FISCAL INCENTIVES FOR RESEARCH AND DEVELOPMENT AND TAX SUBSIDY IN SELECTED EU COUNTRIES
}

\author{
[Fiskální pobídky pro výzkum a vývoj a daňové subvence ve vybraných zemích \\ $\mathrm{EU}]$
}

\author{
Irena Szarowská ${ }^{1}$ \\ ${ }^{1}$ Slezská univerzita, Obchodně podnikatelská fakulta, Univerzitní nám. 1934/3,733 40 Karviná \\ Email:szarowska@opf.slu.cz
}

\begin{abstract}
This article focuses on the fiscal incentives for research and development (R\&D) in 20 selected EU countries. Although the single market is one of the preconditions of the EU functioning, the market for innovation and R\&D within which fiscal incentives operate is very heterogeneous. The article's aim is to compare fiscal incentives and the generosity of tax incentives using the method of Bindex (Warda 2001) and tax subsidy rates. Within the EU, only Germany, Finland and Estonia do not currently have a tax policy aimed directly at stimulating R\&D. The results indicate the existence of substantial differences in provided incentives - from negative support or tax burden (in Germany, Denmark and Finland) to $43 \%$ tax subsidy (for SMEs in France). The most generous R\&D tax incentives are in Portugal, France and Spain. Some countries differentiate the level of subsidy across firm types and offer more generous support for SMEs than for large firms, e.g. subsidy tax rates are $29 \%$ vs. $10 \%$ in the UK and $26 \%$ vs. $43 \%$ in France. In addition, differences are reported in the largesse of tax subsidy by profit scenario - the highest support is reported in a loss-making scenario in France for SMEs.
\end{abstract}

Keywords: B-index, fiscal incentives, innovation, research and development, tax subsidy rate.

JEL classification: $\mathrm{H} 25, \mathrm{O} 38, \mathrm{O} 30$

Doručeno redakci: 9.2.2017; Recenzováno: 21.2.2017; 24.2.2017; Schváleno k publikování: 31.5.2017

\section{Introduction}

Research and development $(\mathrm{R} \& \mathrm{D})$ play a key role in a creation of knowledge, products and technologies. Warda (2005) argues that economic research has long linked R\&D expenditure with economic growth, showing that about $30-50 \%$ of economic growth in society comes from the introduction of new technologies. A competitive and stable tax policy has the potential to be an effective tool for promoting R\&D and innovation in the country or region. The government has a major supporting role in this area by providing a favourable business environment, including appropriate and competitive incentive programs for R\&D. Next Neubig et al. (2016) write fiscal incentives, including tax policies, should be directed at specific barriers, impediments or synergies to facilitate the desired level of investment in R\&D and innovations. R\&D tax policy needs to be considered in the context of the country's general tax policies, its broader innovation policy mix and its other R\&D support policies. Generally, governments have three main instruments for financing $R \& D$ (own $R \& D$, direct and indirect funding), each of which has advantages and disadvantages from the perspective of economic theory (David et al. 2000 or Guellec and van Pottelsberghe 2003). Direct support is focused rather on long-term research, while indirect instruments primarily support short-term applied research and increase incremental innovations (Westmore 2013). The financial crisis obliged many governments to introduce tough fiscal consolidation measures, prioritizing other issues over R\&D. The limited financial resources and urgency to balance expenditure on innovation against expenditure on other policies, force the governments to look for a different innovation policy with new instruments. 
The paper focuses on direct and indirect public support for R\&D and the aim is to compare the generosity of tax incentives using the method of B-index (Warda 2001) and tax subsidy rates. It is organized as follows. Next chapter introduces theoretical background and a short literature review. Chapter 3 provides a description of methodology and data. Empirical part focuses on used direct and indirect instruments for funding $R \& D$ and explores generosity of tax subsidy for R\&D expenditures by profit scenario and firm size in analyzed countries. The last section provides the conclusion, with comments on the main results.

\section{Theoretical backgrounds}

The neoclassical growth model known as Solow-Swan model considers the long-run economic growth (Solow 1956). This model explains the economic growth with the capital accumulation, productivity, population growth and technological progress as the dominant drivers of economic growth and competitiveness. Dzambaska (2013) points out the development of endogenous growth theory has provided many new insights into the sources of economic growth. The essence of the new theory is that growth is a consequence of rational economic decisions. Urbancová et al. (2016) remind the knowledge economy corresponds both to the theories of endogenic growth and especially to the alternative directions for contemporary socio-economic approaches to the theory of growth. Theories incorporating the knowledge economy place an emphasis on the importance of knowledge, information and technical skills, i.e. know-how, as the basic resource for the development of the economy (Lilles and Rõigas 2015).

David et al. (2000) list a number of conceivable positive and negative effects of public R\&D. The thinking behind the concept that publicly funded $R \& D$ should complement private $R \& D$ is partly that an increased marginal return (direct funding) or reduced marginal cost (tax incentives) for R\&D will encourage the companies themselves to conduct more R\&D. There are two positive long-term and dynamic effects of publicly-funded R\&D. First, it can increase the internal stock of scientific knowledge at companies or at other companies by means of spillovers. Secondly, the company's R\&D personnel receive further education and training.

Svensson (2008) presents an overview of the economic literature focused on R\&D and discusses the advantages and disadvantages of different types of publicly funding of R\&D and analyses what differentiates $R \& D$ from other forms of input and why spillover effects occur. He complements the additional positive effects. Public-funding can be used to meet fixed R\&D costs for items (e.g. test facilities or permanent $R \& D$ equipment) that can then be used in the companies' own R\&D activities, thus reducing the average costs for R\&D. Even in the case of contract R\&D (e.g. in the defence industry), private $R \& D$ can be stimulated for several reasons. Fixed start-up costs for R\&D within a particular field can be covered, the ability to assimilate new technology increases within the company and public $R \& D$ contracts signal a future demand for products from the government.

The empirical literature is often focused on studies that econometrically analyses impact of R\&D tax incentives on key policy goals of the instrument. Since a primary goal of R\&D tax incentives is to raise $R \& D$ expenditure by enterprises, most studies look at input additionality, i.e. the change in private $R \& D$ expenditure that can be attributed to the tax incentive (Castellacci and Lie 2015, Hud and Hussinger 2015). The studies are typically based on firm-level panel data and either cover periods before and after the introduction of a tax incentive, or they analyse the effects of changes in the generosity of R\&D tax incentives (Becker 2015). 
Some studies focus on the aggregate national level. For instance, Guellec and Pottelsberghe (2003) estimate that the effect of public funding is the strongest up to a level of approximately 10 per cent of the companies' own R\&D investments - after which the effect declines. Halásková and Bazsová (2016) also use aggregate national data for evaluating the efficiency of R\&D in EU (28) member states and conclude that R\&D efficiency of a given country is influenced by its economic development and potential created for an innovative environment.

Köhler et al. (2012) discuss results of 18 published papers and note that despite a growing number of studies on the impacts of R\&D expenditure and tax incentives, our knowledge about the effectiveness of R\&D expenditure and how a scheme should be designed to maximise its impacts remains limited. They note that little is known about the effects of recently introduced or redesigned fiscal schemes, which often show different design features compared to older programmes. In addition, most empirical studies use data from the manufacturing sector while analyses on the impacts for service firms are rare.

Neubig et al. (2016) state that government support for business R\&D seeks to encourage firms to invest in knowledge that can result in innovations that transform markets and industries and result in benefits to society. Most often, support is provided to firms with the intention of correcting market failure. In addition, countries may use support measures to attract the R\&D activities, investments and jobs of multinational enterprises which typically account for a substantial share of R\&D expenditure. For example, in some small open economies, such as Ireland or Belgium, more than $60 \%$ of business $R \& D$ is accounted for by affiliates of foreign companies (OECD 2016).

The single market is one of the attributes of the EU functioning, nevertheless the market for innovation and $R \& D$ within which fiscal incentives operate is very heterogeneous. It is possible to find next sources of heterogeneity in the market, which may be a prerequisite for potential incentives:

- types of innovation,

- types of R\&D expenses,

- types of R\&D business models,

- types of firms,

- types of financing,

- other economic and policy conditions in a country as bankruptcy laws or patent protection.

There is also considerable heterogeneity within types of fiscal incentives. Governments offer direct support through public procurement for R\&D and a variety of grants, subsidies, loans or equity funding. Indirect public funding is mostly realized as tax incentives and it is usually more neutral than direct support in terms of industry, region and firm characteristics, although this does not exclude some differentiation, most often by firm size (OECD 2010). Tax incentives reduce the marginal cost of $\mathrm{R} \& \mathrm{D}$ and innovation spending. Tax incentives applicable to different tax arrangements, including corporate and personal income taxes, are also widely used to encourage private investments in R\&D and the exploitation of IP assets, to attract business angels and leverage early-stage finance, and to attract foreign talent or foreign multinationals.

Moreover, a country's general tax rules can be an important attraction or deterrent to risk-taking innovators. Huňady et al. (2014) and Akcigit et al. (2015) claim that tax rates matter to the location of inventors and their patent registrations. The tax rates that mattered were personal income tax rates of the inventors, and those who were employed likely to take advantage of 
personal income tax differentials. Favourable tax treatment of employee stock options can make them more attractive to employers than paying cash salaries, as they help to reduce cash outflows (Edgerton 2010). Labour taxes, particularly employer payroll taxes, can significantly increase the cost of doing business in a particular country. Tax loss limitation rules and choice of business entity can affect the general business tax climate as well as the value of particular targeted R\&D tax incentives.

\section{Methodology and data}

The paper examines 20 European countries, namely Austria (AT), Belgium (BE), the Czech Republic (CZ), Denmark (DK), Estonia (ES), Finland (FI), France (FR), Germany (DE), Greece (GR), Hungary (HU), Ireland (IR), Italy (IT), Netherlands (NL), Poland (PL), Portugal (PT), Slovakia (SK), Slovenia (SI), Spain (SP), Sweden (SW) and the United Kingdom (UK). The selection of country sample is limited to data availability. This empirical evidence is based on data (the latest available - year 2015) collected from the Eurostat and OECD database, benchmark tax data information, including statutory corporate income tax rates, is obtained from the OECD Tax Database.

As already noted, the aim of the article is to compare the generosity of tax incentives using the method of B-index (Warda 2001 and 2005) and tax subsidy rates, all variables are described in detail in Thomson (2012). Tax subsidy is an experimental indicator based on quantitative and qualitative information representing a national level of tax subsidy rate under different scenarios. The tax subsidy rate is calculated as 1 minus the B-index (Warda 2005). The origin of the name "B-index" captures the fact that the model describes the minimum benefit-cost ratio at which an R\&D investment becomes profitable given a jurisdiction's income tax treatment for firms performing this work. The B-index $(B)$ is defined as a minimum present value of before-tax income necessary to pay the cost of $\mathrm{R} \& \mathrm{D}$ and to pay the corporate income taxes, so that it becomes profitable for the firm to conduct R\&D:

$$
1-B=\text { tax subsidy (if positive) or tax burden (if negative) }
$$

The B-index measures the relative attractiveness of $R \& D$ tax treatment in the country or region. It is based on well-founded economic theory and designed so that it is easy to apply and capable of including all tax parameters, and can be used as a policy analysis tool (Šeligová 2016). The model is based on the marginal effective tax rate and contains an overall measure of the corporate tax burden on marginal $\mathrm{R} \& \mathrm{D}$ investments in different countries, therefore it allows international benchmarking of the attractiveness of $R \& D$ tax systems. The model includes the following components of $R \& D$ cost structure and applicable tax provisions:

- Current expenditures: wages and salaries of R\&D personnel and the cost of materials used in the $R \& D$ process.

- Capital expenditures incurred in R\&D: the cost of machinery and equipment (ME) and facilities/buildings.

- Depreciation of capital assets used in R\&D: these assets are typically depreciated over the useful life according to two methods.

- Additional allowances on R\&D expenditures: these provisions allow firms conducting $R \& D$ to deduct more from their taxable income than they actually spend on $R \& D$.

- Tax credits: credits are applied against income tax payable. The benefit of the credit can be non-taxable or taxable.

- Statutory corporate income tax rates. 
For consistent comparisons, the model measures country B-indexes under constant and uniform technical assumptions. In accordance with Warda (2005) and OECD (2016) the assumptions include:

- R\&D expenditures are split into current expenses and capital expenses, using an average proportion of $90 \%$ and $10 \%$, respectively.

- Wages and salaries represent (a component of current costs) $60 \%$ of total R\&D expenditures.

- Capital expenses are divided equally between machinery and equipment (5\%), and buildings $(5 \%)$.

- Time factor: the B-index model is expressed in present value terms. It is assumed that for all the countries compared, the discount rate is constant and holds at $10 \%$.

The basic formula for B-index is defined in equation (2).

$$
B=\frac{1-A}{1-t}
$$

where $B$ is B-index, $A$ is the net present discounted value of depreciation allowances, tax credits and other $\mathrm{R} \& \mathrm{D}$ tax incentives available (i.e. after-tax cost), $t$ is corporate income tax rate. For example, in the case of a $\theta$ allowance rate on $\mathrm{R} \& \mathrm{D}$ (deduction from taxable profits) $A=t \theta$. When $\theta=1$, current expenditures are fully $(100 \%)$ deductible, the benchmark scenario in most countries, $B=1$ and the subsidy rate is zero.

In recent years, the adverse economic climate has dented the profitability of many companies. In recognition of the fact that there are significant differences in the provisions made by countries for scenarios in which companies cannot immediately realise the entire value of tax incentives on R\&D, OECD (2013) amends and generalised the B-index formula as follows:

$$
B=\frac{1-t(x+(1-x) \psi) \theta}{1-t(x+(1-x) \psi}
$$

In this formula, if the firm has a sufficiently large profit to claim the incentives, then $x=1$ and $x=0$ otherwise. $\psi$ is the net present value adjustment factor for the allowance (or equivalent incentive) in the scenario with an insufficiently large profit base ("loss making" for brevity). $\psi=1$ if the incentive is fully and immediately refundable in the "loss" case and $0<\psi<1$ if the incentive can be carried forward (for more details look at OECD, 2013).

The value of $\psi$ has been modelled, using some additional, simplifying assumptions, to reflect the terms of carry-forward provisions as well as instances when refunds are postponed for a given number of years if not previously used. A firm with low or negative profits faces an implicit lower tax rate $\tau=t \psi$ through which to realise the incentives theoretically available. For this reason, when $\theta>1$, i.e. when the tax system subsidises $\mathrm{R} \& \mathrm{D}, B$ index (loss) $>B$ index (profit) and the subsidy rate is lower for loss than for profit making firms. In the opposite case, when $\theta<1$ (e.g. where no incentives are provided and R\&D capital costs cannot be immediately amortised), a net tax is in place and the breakeven point is thus higher in the profit-making case $B$ index (loss) $<$ B index (profit).

In the case where authorities apply different carry forward provisions to general losses and special allowances and credits, the following formulation has been derived to its final form in (4):

$$
B=\frac{1-t\left(x \theta+(1-x) \psi_{\infty}\left(1+\frac{(\theta-1) \psi^{\mathrm{T}}}{\psi}\right) \theta\right.}{1-t\left(x+(1-x) \psi_{\infty}\right.}
$$


where $\psi_{\infty}$ is the expected net present value of a unit of loss which can be carried forward indefinitely, and $\psi^{T}$ is the net present value that reflects a time limit $T$ for carrying forward special credits and allowances.

The model is confined to tax measures related specifically to the R\&D decision at the corporate level. Some countries may offer no R\&D tax incentives but compensate for this by taxing investment income very lightly. Thus broader investigation could result in a different ranking of national tax systems. The model excludes incentives related to personal income, value added, property taxes, as well as taxes on wealth and capital and other forms of direct government support (grants and subsidies). These differences are not included in the calculations.

\section{Results and discussion}

\subsection{Financial support for $R \& D$ and fiscal incentives}

Expenditure on R\&D are regularly monitored by national statistical offices and periodically reported by Eurostat and OECD. The system of R\&D indicators is accurately defined and used for international comparisons. It is possible to find basic definitions needed for this examination in Frascati Manual (OECD 2015a). Gross domestic expenditure on R\&D (GERD) is usually reported for sectors of performance: business enterprise, higher education, government and private not for profit institutions serving households. Business enterprise expenditure on R\&D (BERD) records gross expenditures on $\mathrm{R} \& \mathrm{D}$ performed by all firms, organisations and institutions whose primary activity is the production of goods and services (other than higher education) for sale to the general public at an economically significant price, and the private non profit institutions mainly serving them.

Figure 1: Gross domestic expenditure on R\&D in percentage GDP (2015)

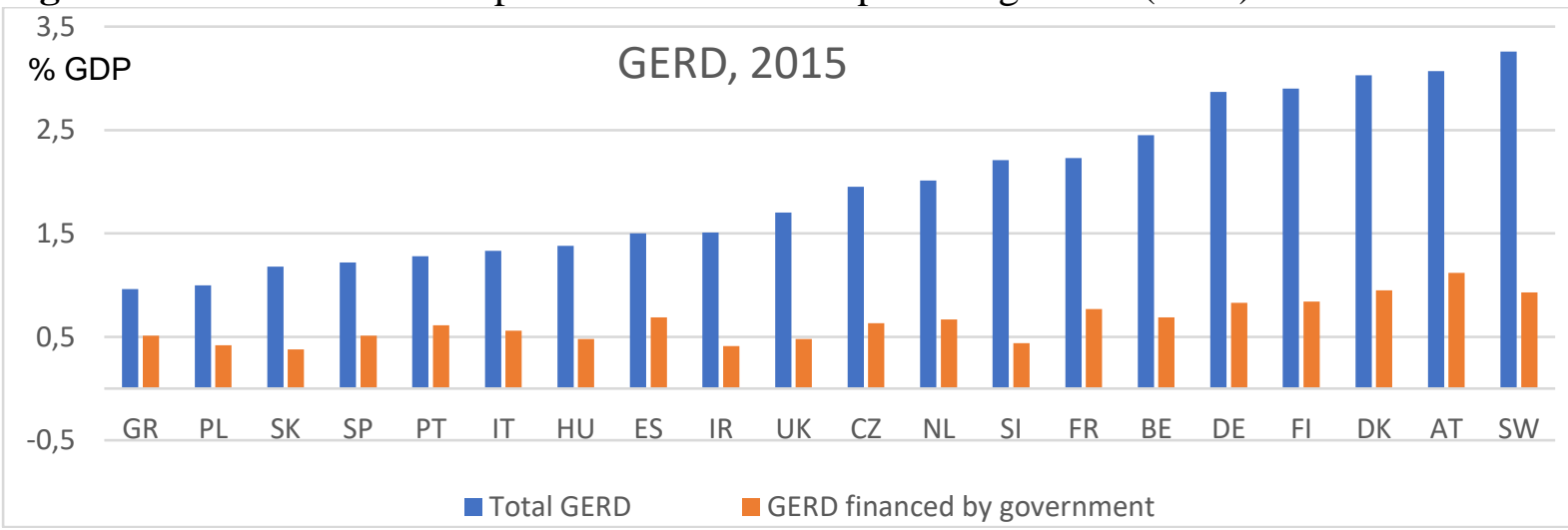

Source: author's compilation based on data from OECD (2016])

It is known that R\&D is vital for the knowledge-based economies' competitiveness in a globalized world and support of $R \& D$ and innovation is also a political measure. Both the Europe 2020 strategy and its predecessor the Lisbon agenda (launched in 2000) set similar targets in relation to $R \& D$ expenditure, namely that expenditure on $R \& D$ should be equivalent to at least $3.00 \%$ of the EU's GDP and the appropriate split for R\&D is $1 / 3$ financed by public funds and $2 / 3$ by private. Fig. 1 reports total R\&D expenditure (GERD) and R\&D financed by government in the European Union in 2015. Average EU-28's GERD was 2.04\% GDP, a share financed by government was $0.66 \%$ GDP (Eurostat database). Fig. 1 suggests that the smallest R\&D expenditure is reported notably in countries deeply hit by European debt crisis e.g. Greece, Spain, Portugal, Italy.

Government-funded business $R \& D$ is the component of $R \& D$ performed by business enterprises attributed to direct government funding. It includes grants and payments for R\&D 
contracts for procurement, but not $\mathrm{R} \& \mathrm{D}$ tax incentives, repayable loans or equity investments. Fig. 2 reports total government support of business R\&D in 2015 divided into direct government funding of BERD and indirect government through R\&D tax incentives based on data from OECD (2015b).

Figure 2: Total government funding of business R\&D in 2014 (\% GDP)

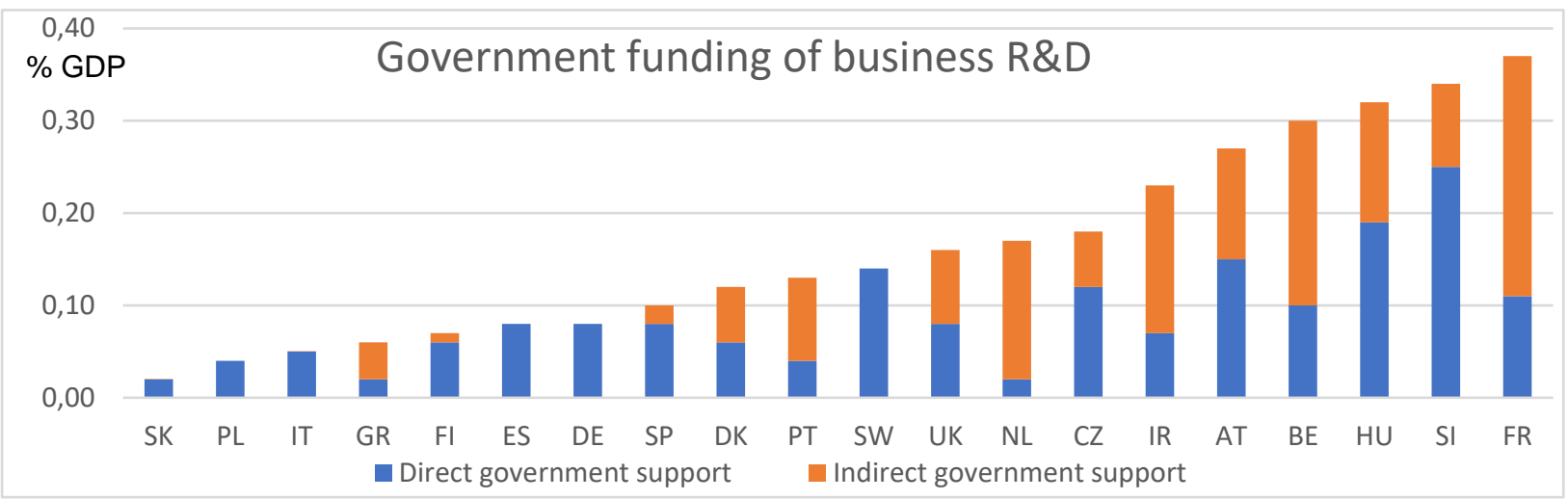

Source: author's compilation based on data from OECD (2016)

Current governments often combine direct public funding from both national and EU sources and indirect public funding with the aim to stimulate private R\&D activity in order to enhance job creation and economic growth. Direct support can be implemented through public procurement in $\mathrm{R} \& \mathrm{D}$, by providing grants, subsidies, loans and corporate financing (OECD 2014) as it is shown in Fig. 3. Grants and subsidies are the most common funding instruments. Individual tools are described in Szarowská (2015).

Figure 3: Direct funding instrument for R\&D

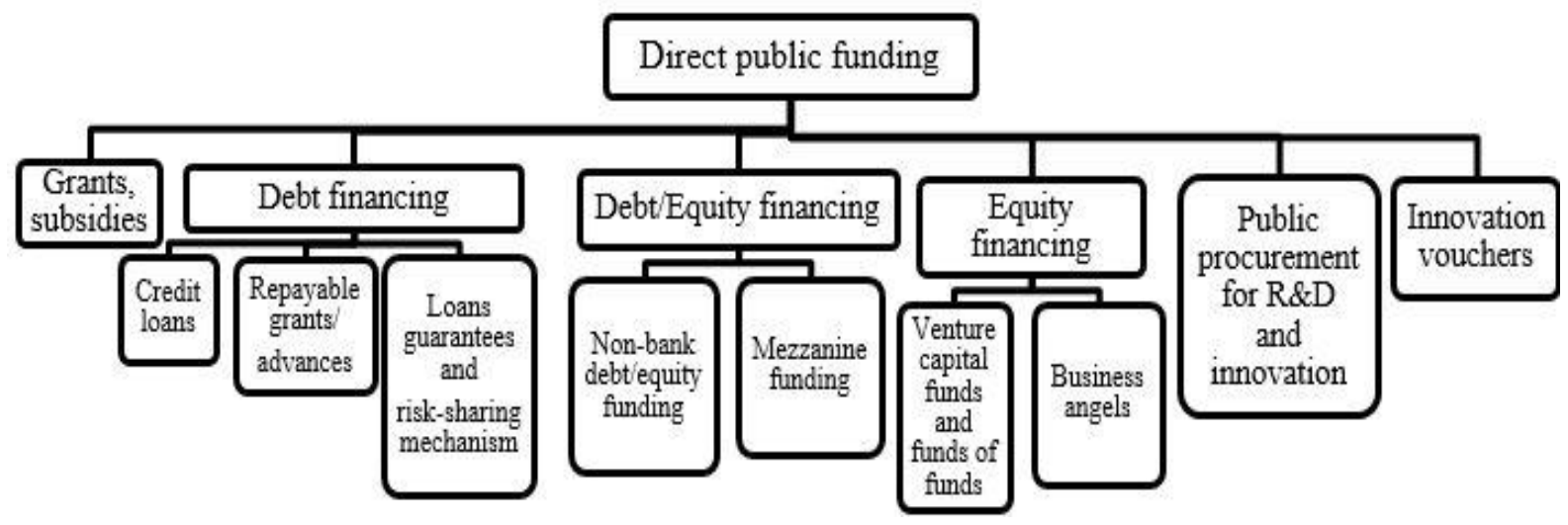

Source: Szarowská (2015)

Indirect support in recent years become more important to encourage investment in R\&D and at least one form of stimulus R\&D currently exists in 25 EU countries (OECD 2015c). Within the EU, only Germany, Finland and Estonia do not currently have a tax policy aimed directly at stimulating innovation (year 2015). Although tax incentives are common, they are far from homogeneous and differ substantially across countries, with most countries offering more than one type of instrument. R\&D tax credits are the most popular type of incentive followed by enhanced allowances and accelerated depreciation. Tools also include reduction of social security contributions, exemption from customs duties, preferential loans, venture capital support, and advantageous lease of regional and central infrastructure (OECD 2015c and Deloitte 2015). 
Table 1: Tax incentives for $R \& D$ and innovation

\begin{tabular}{|l|l|c|}
\hline Tax arrangements & Expenditure-based & Income-based \\
\hline Corporate income tax & $\begin{array}{l}\text { AT, BE, CZ, DK, FR, GR, HU, IT, PO, } \\
\text { PT, SK, SI, SP, UK }\end{array}$ & $\begin{array}{l}\text { BE, GR, HU, IT, NL, PO, SP, } \\
\text { UK }\end{array}$ \\
\hline $\begin{array}{l}\text { Payroll withholding and } \\
\text { social security taxes }\end{array}$ & BE, FR, HU, NL, SP, SW & \\
\hline Personal income tax & DK, HU & DK \\
\hline Value-added tax & PO & \\
\hline Other taxes & FR, IT, PT & \\
\hline No tax arrangements & ES, FI, DE & \\
\hline
\end{tabular}

Source: OECD (2015b,c and 2016)

Tab. 1 summarises expenditure-based and income-based tax arragements applied in the selected EU countries in 2015. R\&D tax incentives aim to encourage firms to perform $R \& D$ by reducing its costs. Compared with direct subsidies, $R \& D$ tax incentives allow firms to decide the nature and orientation of their R\&D activities, on the assumption that the business sector is best placed to identify research areas that lead to business outcomes. R\&D tax incentives are marketfriendly instruments that are by nature more neutral than direct support instruments. A variety of tax incentives for R\&D and innovation apply to corporate income tax, payroll withholding taxes and social security contributions, personal income tax, value-added tax or other consumption, land and property taxes, etc. Tax breaks are granted on the basis of expenditures incurred for R\&D activities (expenditure-based) or gains from innovative activities (incomebased).

\subsection{Generosity of tax subsidy in selected EU countries}

As OECD (2014) highlights the diversity of national R\&D tax arrangements makes crosscountry comparisons difficult. In addition, the relative generosity and attractiveness of national R\&D tax incentives depend not only on eligibility rules and design features, but also on the taxation system of a country, e.g the level of corporate taxation, or on firms' ability to claim and use incentives, such as their capacity to make a profit against which potential tax relief on taxes can be applied or their human and financial capacity to administer claims for R\&D tax incentives and incur the related costs.

One way to compare the generosity of tax incentives between countries, while taking differences in corporate tax rates into account, is to calculate tax subsidy rates.

The following variables were used for the calculation:

- the corporate income rate,

- the tax price of labour related to $R \& D$ expenses,

- the tax price of machinery and equipment used for the purposes of R\&D,

- the tax price of buildings and structures,

- the tax price of other current (non - labour) expenses (these are the same as labour expenses in all countries except where there exist special credits or deductions for wages and overheads or per employee)

- the tax price for $R \& D$ expenditure that applicable to cross border R\&D.

Fig. 4 shows tax subsidy rates across EU countries, calculated in line with (5) as one minus the B-index defined in equition (4).

$$
1-B=1-\frac{1-t\left(x \theta+(1-x) \psi_{\infty}\left(1+\frac{(\theta-1) \psi^{\mathrm{T}}}{\psi}\right) \theta\right.}{1-t\left(x+(1-x) \psi_{\infty}\right.}
$$


The tax subsidy rates are distinguished by firm size and profitability status. A decline in the Bindex reflects an increase in R\&D tax generosity. The B-index for the profit scenario assumes that the "representative firm" generates a sufficiently large profit to achieve the incentive's full potential benefit. An adjusted B-index is reported for a loss-making firm that is unable to claim tax benefits in the reporting period. Using the adjusted effective tax rate takes into account refundability and carry-forward provisions.

Figure 4: Tax subsidy rates for R\&D expenditures by profit scenario and firm size (2015)

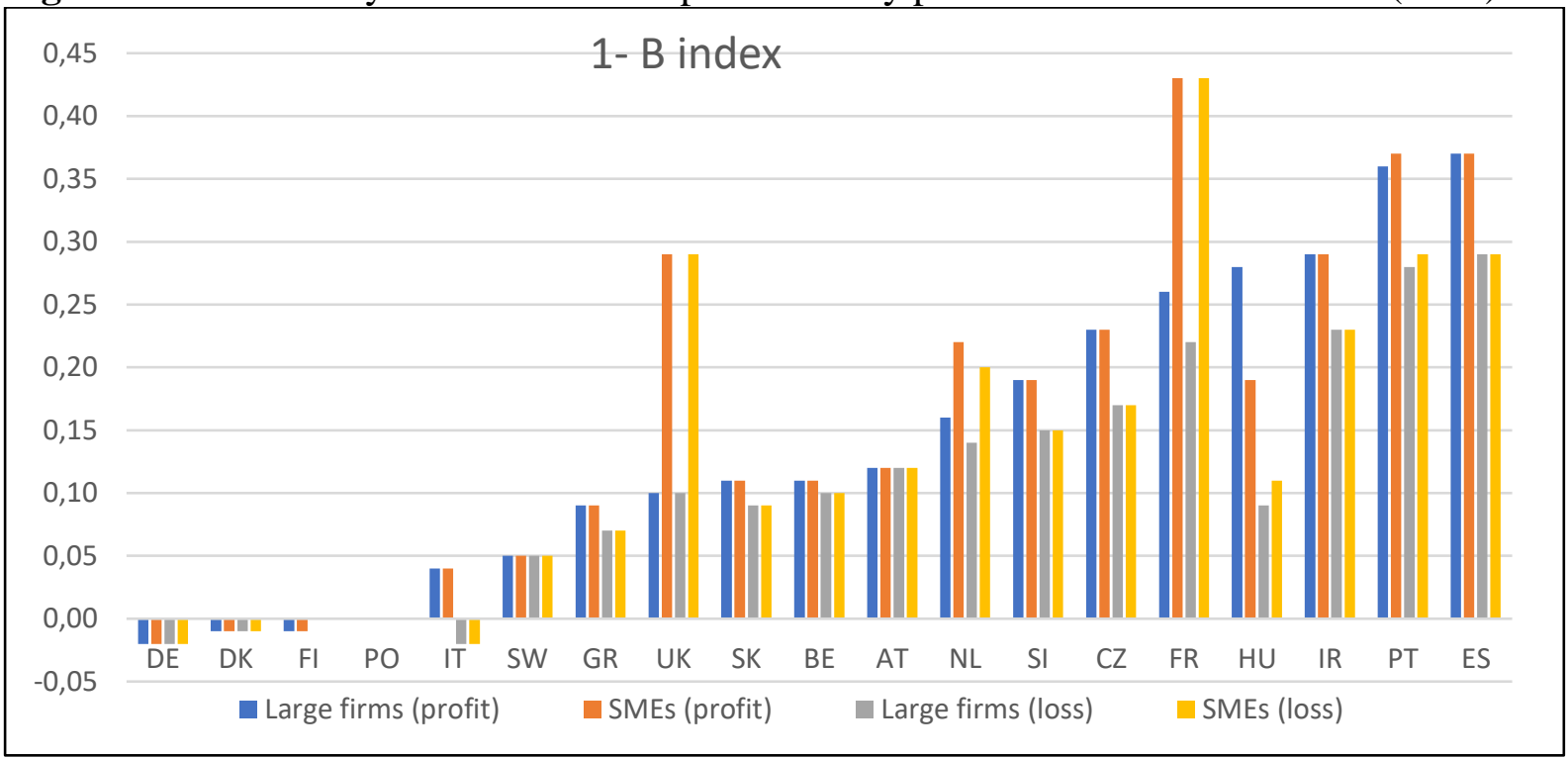

Source: author's calculations based on data from OECD (2015b,c and 2016), OECD tax database, Deloitte (2015).

The Fig. 4 displays tax subsidy rates for large firms and SMEs. The definitions of SMEs and large firms vary across countries and may also vary over time. In France, Italy, the Netherlands, Portugal and Spain, special tax incentive provisions are available for young innovative firms, start-ups and innovative SMEs, as a subgroup of the SME population. Definition of SME subgroup-specific can be found in the country-specific notes of OECD (2015b). However, Bindex does not take into account ceilings- it assumes a 'representative firm' whose expenditure does not exceed the maximum allowed level of benefit.

The highest generosity of R\&D tax incentives is found in Portugal, France and Spain. Countries differentiate the level of generosity across firm types. This is reflected in the Fig. 4, where Portugal, the Netherlands and especially France and the United Kingdom offer a more generous treatment for SMEs than for large enterprises (subsidy tax rate are 29\% vs. 10\% in UK and 26\% vs. $43 \%$ in France). Moreover, SMEs that do not have profits enjoy the same level of tax generosity as profitable SMEs in France and the United Kingdom. The detected level of subsidy support is interesting in a contex of conclusions done by Guellec and Pottelsberghe (2003) who estimated that the effect of public funding is the strongest up to a level of approximately $10 \%$ after which the effect declines.

The results in Fig. 4 also present the largesse of tax subsidy by profit scenario. In a profitmaking scenario, Portugal and Spain provide the most generous tax mix for R\&D. However, tax arrangements are more favourable for SMEs and young innovative firms in France, the Netherlands, Portugal and the United Kingdom where start-ups and small firms benefit from higher deduction rates. In France since 2004, new firms classified as young innovative firms get large exemptions on corporate income tax and social security contributions. In a loss- 
making scenario, the tax subsidy rate on $R \& D$ expenditure is markedly lower for both large and small firms. On the other hand, the gap is particularly significant in Hungary, where R\&D tax allowances do not include any carry-forward or refundable options. Therefore, subsidy tax rates for large firms and SMEs are $28 \%$ and $19 \%$ by profit scenario $9 \%$ and $11 \%$ for loss-making scenario.

Negative value of this indicator means negative tax subsidy rates or tax burden. This is reported for all firm size and profitability status in Germany, Denmark and Finland, as well as in lossmaking scenario in Italy.

\section{Conclusion}

The aim of the article was to compare fiscal incentives and the generosity of tax incentives using the method of B-index (Warda 2001) and tax subsidy rates. The empirical evidence done for $20 \mathrm{EU}$ countries is based on data from Eurostat and OECD database. It is found that governments finance R\&D and innovation through a mix of direct and indirect instruments. Due to limited financial resources, indirect support has become more important in recent years. Within the EU, only Germany, Finland and Estonia do not currently have a tax policy aimed directly at stimulating innovation. Although tax incentives are common, they are heterogeneous and differ substantially across countries; most countries offer more than one type of instrument. R\&D tax credits are the most popular type of incentive, followed by enhanced allowances and accelerated depreciation.

A way to compare the largesse of tax incentives between countries, while taking differences in corporate tax rates into account, is to estimate tax subsidy rates calculated as one minus the Bindex (Warda 2001). The B-index demonstrates the potential of the national tax and innovation system to attract investment in R\&D. It is important to note that although the single market is one of the attributes of the EU functioning, generosity of fiscal incentives vary significantly across the EU countries. The results indicate the existence of substantial differences in provided incentives - from negative support or tax burden (in Germany, Denmark and Finland) to 43\% tax subsidy (for SMEs in France). The most generous R\&D tax incentives are in Portugal, France and Spain. Countries differentiate the level of generosity across firm types and offer more generous treatment for SMEs than for large firms, e.g. France and the United Kingdom offer a distinctly broadminded support for SMEs than for large firms (subsidy tax rates are 29\% vs. $10 \%$ in the UK and $26 \%$ vs. $43 \%$ in France). Differences are found in the largesse of tax subsidy by profit scenario. Portugal and Spain provide the most generous tax subsidy for all firms in loss (29\%), but the highest support is reported in a loss-making scenario in France for SMEs $(43 \%)$.

Methodology of B-index and tax subsidy rates can be used to monitor changes in the level of attractiveness of R\&D tax treatment in individual countries and policy makers as well as firms may apply it as an instrument in cross-country and cross-time evaluations of policy tools with respect to their impact on incremental private sector R\&D expenditure.

\section{Acknowledgements}

This paper was supported by the Ministry of Education, Youth and Sports Czech Republic within the Institutional Support for Long-term Development of a Research Organization in 2017. 


\section{References}

[1] AKCIGIT, U., S. BASLANDZE, and S. STANTCHEVA, 2015. Taxation and the International Mobility of Inventors. [online]. Available at: http://www.nber.org/papers/w21024. [Accessed: 2017, 27].

[2] BECKER, B., 2015. Public R\&D Policies and Private R\&D Investment: A Survey of the Empirical Evidence. Journal of Economic Surveys, 29(5), 917-42. ISSN 1467-6419.

[3] CASTELLACCI, F. and CH. M. LIE, 2015. Do the effects of R\&D tax credits vary across industries? A meta-regression analysis. Research Policy, 44(4), 819-832. ISSN 0048-7333.

[4] DAVID, P. A., H. H. BRONWYN and A. A. TOOLE, 2000. Is public R\&D a complement or substitute for private R\&D? A review of the econometric evidence. Research Policy, 29(4-5), 497-529. ISSN 0048-7333.

[5] DELOITTE, 2015. Global Survey of $R \& D$ Tax Incentives 2015. [online]. Available at: https://www2.deloitte.com/content/ dam/Deloitte/global/Documents/Tax/dttl-tax-globalrd-survey-aug-2015.pdf. [Accessed: 2016, June 2].

[6] DZAMBASKA, E., 2013. Empirical analysis of FDI and tax incentives on the economic growth in the Republic of Macedonia. Economic Development (Економски Развој), 15(3), 103-127. ISSN 1857-7741.

[7] EDGERTON, J., 2010. Investment incentives and corporate tax asymmetries. Journal of Public Economics, 94(11), 936-952. ISSN 0047-2727.

[8] GUELlEC, D. and B. VAN POTTELSBERGHE, 2003. The impact of public R\&D expenditure on business R\&D. Economics of Innovation and New Technology, 12(3), 225243. ISSN 1043-8599.

[9] HALÁSKOVÁ, M. and B. BAZSOVÁ, 2016. Evaluation of the efficiency of research and development in EU countries. Acta academica karviniensia, 16(4), 32-45. ISSN 1212$415 \mathrm{X}$.

[10] HUD, M. and K. HUSSINGER, 2015. The impact of R\&D subsidies during the crisis. Research Policy, 44(10), 1844-1855. ISSN 0048-7333.

[11] HUŇADY, J., M. ORVISKÁ and B. ŠARKANOVÁ, 2014. Determinants of European Firm' s Innovation and the Role of Public Financial Support. European Financial and Accounting Journal, 9(1), 62-84. ISSN 1802-2197.

[12] KÖHLER C., P. LAREDO and C. RAMMER, 2012. The impact and effectiveness of fiscal incentives for $R \& D$. NESTA Working Paper N. 12/01. [online]. Available at: www.nesta.org.uk/sites/default/files/the_impact_and_effectiveness_of_fiscal_incentives. pdf. [Accessed: 2015, June 27].

[13] LILLES, A. and K. RÕIGAS, 2015. How higher education institutions contribute to the growth in regions of Europe? Studies in Higher Education, 21(14), 65-78. ISSN 03075079

[14] NEUBIG, T., F. GALINDO-RUEDA, S. APPELT, CH. CRISCUOLO and M. BAJGAR, 2017. Fiscal incentives for $R \& D$ and innovation in a diverse world. [online]. Available at: http://www.keepeek.com/Digital-Asset-Management/oecd/taxation/fiscal-incentivesfor-rd-and-innovation-in-a-diverse-world_5jlr9stckfs0-en. [Accessed: 2017, January 27].

[15] OECD, 2010. R\&D tax incentives: Rationale, design, evaluation. [online]. Available at: http://www.oecd.org/sti/ind/46352862.pdf. [Accessed: 2016, June 2]. 
[16] OECD, 2013. Definition, interpretation and calculation of the B index. [online]. Available at: https://www.oecd.org/sti/b-index.pdf. [Accessed: 2016, June 2].

[17] OECD, 2014. OECD Science, Technology and Industry Outlook 2014. Paris: OECD Publications Service. ISBN 9789264222281.

[18] OECD, 2015a. Frascati Manual 2015. Paris: Organisation for Economic Cooperation and Development. ISBN 9789264239012.

[19] OECD, 2015b. OECD Science, Technology and Industry Scoreboard 2015. Paris: Organisation for Economic Cooperation and Development. ISBN 9789264239784.

[20] OECD, 2015c. Compendium of $R \& D$ tax incentive schemes: OECD countries and selected economies. [online]. Available at: http://www.oecd.org/sti/rd-tax-incentivescompendium.pdf. [Accessed: 2017, January 27].

[21] OECD, 2016. OECD Science, Technology and Innovation Outlook 2016. Paris: Organisation for Economic Cooperation and Development. ISBN 978-92-64-26306-2.

[22] SOLOW, R., 1956. A Contribution to the Theory of Economic Growth. The Quarterly Journal of Economics, 70(1), 65-94. ISSN 0033-5533.

[23] SVENNSON, R., 2008. Growth through Research and Development - What Does the Research Literature Say? Stockholm: Vinnova. ISBN 978-91-85959-33-4.

[24] SZAROWSKÁ, I., 2015. Direct and indirect public funding tools for research and development used in European Union countries. In Proceedings of the 13th International Conference Economic Policy in the European Union Member Countries. Ostrava: Faculty of Economics VSB - Technical University, pp. 687-696. ISBN 978-80-248-3796-3.

[25] ŠELIGOVÁ, M., 2016. The Effects of R\&D Intensity and Tax Incentives on Firms Growth of PIGS Countries. European Financial and Accounting Journal, 11(2), 53-68. ISSN 1802-2197.

[26] THOMSON, R. K., 2012. Measures of R\&D Tax Incentives for OECD Countries. [online]. Available at: https://papers.ssrn.com/sol3/papers.cfm?abstract_id=2146399. [Accessed: 2016, June 2].

[27] URBANCOVÁ, H., L. VNOUČKOVÁ and Š. LABOUTKOVÁ, 2016. Knowledge transfer in a knowledge-based economy. E\&M Economics and Management, 19(2), 73-86. ISSN 1212-3609.

[28] WARDA, J., 2001. Measuring the Value of R\&D Tax Treatment in OECD Countries Science and technology. STI Review, 27, 185-211. ISSN 1609-7637.

[29] WARDA, J., 2005. Measuring the Value of $R \& D$ Tax Provisions. A primer on the B-index Model for Analysis and Comparisons. Ottawa: JPW Innovation associates. ISBN 92-6417581-4.

[30] WESTMORE, B., 2013. $R \& D$, Patenting and Growth. OECD Economics Department Working Papers. [online]. Available at: http://www.oecd-ilibrary.org /content/workingpaper/5k46h2rfb4f3-en. [Accessed: 2015, June 27]. 